\title{
educação

\section{The Importance of Teacher Agency and Expertise in Education Reform and Policymaking}

\author{
Ken ZEICHNER \\ University of Washington, United States of America
}

\begin{abstract}
This paper asserts that teacher agency and expertise are often underutilized in education systems throughout the world, and that by encouraging greater teacher agency and better leveraging and utilizing the collective expertise of teachers, educational systems can become more successful and more equitable. It summarizes several arguments for government officials who are responsible for education in their countries to support the development of genuine teacher agency with regard to their teaching and professional learning experiences, and to give teachers collectively a greater voice in the conceptualization and development of education policies. The goal here is to support teacher agency and to benefit from teachers' expertise in ways that are connected to system goals to provide everyone's children with access to well-prepared teachers and a high quality and enriching education that addresses academic, socialemotional, and civic aspects of learning and that reflects the multicultural and global realities that affect all nations.
\end{abstract}

Keywords: Teacher agency; Teacher policy; Teacher expertise

\section{IN T RODU C TION}

In this paper ${ }^{1}$, I argue that teacher agency and expertise are often underutilized in education systems throughout the world, and that by encouraging greater teacher agency and better leveraging and utilizing the collective expertise of teachers, educational systems can become more successful and more equitable. The thoughts that are expressed in this brief paper are based on my participation as a researcher in a recent study of teacher policy and practice in several high performing education systems around the world that were deemed to be high performing, both because of the overall quality of student learning, and the equity in their distribution of educational resources and student learning outcomes (Darling-Hammond, Burns, et al., 2017). These thoughts also are based on my experiences over the last 43 years in supporting and studying teacher professional learning and teacher policy especially in relation to issues of equity and social justice (e.g., Caro-Bruce, Flessner, Klehr, \& Zeichner, 2007; Zeichner, 1993).

1 This paper is based on a keynote address presented at the Seoul International Education Forum, sponsored by the Seoul Metropolitan Office of Education, in October 2018. 


\section{TEACHER AGENCY}

Teacher agency is a term that has been used to refer to situations where teachers have the capacity to exercise their discretion and judgment in adapting their instruction and curriculum to meet the diverse and changing needs of their students (Priestley, Biesta, \& Robinson, 2015). It has also been used to refer to "the capacity of teachers to act purposefully and constructively to direct their professional growth, and to contribute to the growth of their colleagues" (Calvert, 2016, p. 4). Finally, teacher agency has also been used to include teachers' capacity to have a genuine voice in helping to shape educational policies (Atkin, 1994).

I have decided to use the term teacher agency rather than autonomy because I believe that the term agency better reflects the responsibilities of teachers, administrators, and policymakers to support both teachers' judgments with regard to their own students' ongoing learning, their own professional growth, their voice in the policies that affect their work in the classroom, and the achievement of education system priorities that seek to guide the learning of students and staff toward the provision of a high quality and equitable education for all students.

A choice does not have to be made between teacher agency and compliance. High performing and equitable education systems around the world have demonstrated that it is possible to both support genuine teacher professionalism by enabling their agency with regard to student learning, teacher learning, and education policymaking, and to support system guidance towards achieving a more enriching and equitable education for all students (Darling-Hammond, Burns, et al., 2017).

\section{TEACHER EXPERTISE}

Individual teachers have knowledge and skills that they have brought to and have acquired in their initial teacher education programs, in their teaching, and in their ongoing professional learning experiences, that are often underutilized by education systems. In using the term teacher expertise, I am referring to more than individual teacher knowledge and skills. I am also identifying the teacher expertise achieved and employed by teachers collectively in individual schools and across educational systems (Priestley et al., 2015). Hargreaves and Fullan (2012) argue that teacher expertise (or what they call professional capital) consists of the confluence of three kinds of expertise: human capital, social capital, and decisional capital. Human capital refers to the individual talent that teachers have and continually develop. Social capital refers to the collective expertise that comes from genuine teacher collaboration. Decisional capital comes from creating conditions to enable teachers to exercise their professional judgment with regard to student learning, teacher learning, and from teachers' voices being heard by educational policymakers.

This view of teachers as professionals who work in conditions and in a culture that support their agency with regard to teacher learning, student learning, and educational policy was found in all of the high performing education systems that we recently studied (DarlingHammond, Burns, et al., 2017) and is supported by much international research on teacher professional learning (e.g., Asia Society, 2017; Day, 2012; Hill, Beisiegel, \& Jacob, 2013; Jensen, Sonnemann, Roberts-Hull, \& Hunter, 2016; Stewart, 2012; Tatto, 2007; Villegas-Reimers, 2003). It is a view that considers teachers to be both critical consumers and producers of 
new education knowledge (Cochran-Smith \& Lytle, 1993; Zeichner, 1995), and that views the relationship between policy and practice as a democratic and interactive one, rather than one that moves only top down from policy to practice.

I discuss three examples of cases in the U.S. and Canada where supporting the agency of professional teachers and taking better advantage of their individual and collective expertise has led to influences on policy and to greater equity and social justice in education for students. Before I briefly describe these three cases here, I will outline several different strategies that have been used in successful education systems to support teacher agency and access teacher expertise.

\section{Strategies For DeVEloping AND BENEFITING FROM TEACHER} AGENCY AND EXPERTISE

There are several strategies that have been utilized in successful education systems for enabling and benefiting from teacher agency and expertise. These include supporting teacher action research for both individual teachers and groups of teachers within an education system (Caro-Bruce et al., 2007). In some cases, teacher researchers focus on issues and topics that are given to them by administrators, while in other cases teachers determine the substance of their collaborative work. Some research groups are led by the teachers in the groups while in other cases outside facilitators are present.

In one notable case in Alberta, Canada, the provincial government funded action research projects by teachers, principals, and communities in individual schools and groups of schools over a 14 -year period, and demonstrated, through independent research, the achievement of a substantial impact on the improvement of educational quality and equity (Hargreaves \& Shirley, 2012). In some cases, like in Shanghai, teacher action research is built into the way in which teachers' work is constructed (Campbell, Zeichner, Lieberman, \& Osmond-Johnson, 2017). In other situations, teacher action research is an added professional learning opportunity for some teachers beyond their contracted teaching hours (Zeichner, 2003).

There is substantial evidence that teacher action research, conducted under particular conditions (Zeichner, 2003; Zeichner \& Noffke, 2001), benefits not only the teachers conducting the research, but also other educators as well, and that action research is a mechanism for both knowledge creation and professional learning. For example, in the Madison Wisconsin school district in the U.S., where I supported the research of teachers for 25 years, at the end of each school year teachers present the findings of their year-long action research to other educators in the school district and to school district administrators. The studies done by teachers are also published by the school district each year and copies are sent to the libraries in each school. In addition, some teachers here and in other parts of the U.S. choose to present their research at national and international educational research conferences and to publish their work in journals or in book form (Caro-Bruce et al., 2007; Zeichner \& Noffke, 2001).

Another closely related inquiry strategy that has been used to support teacher agency and to leverage and benefit from their expertise is lesson study (Lewis \& Lee, 2018). Lesson study is a particular form of classroom-based inquiry that exists in several countries in which small groups of teachers collaboratively plan, teach, observe, revise and reteach individual class lessons. In some cases, as in Japanese primary 
schools, lesson study is part of the structure of most teachers' work, and in other cases the availability of this inquiry practice to teachers is more limited.

A third general approach to support teacher agency and benefit from teacher expertise is the use of professional learning communities (PLCs). PLCs have emerged in many educational systems across the world as an alternative to a focusing on individual teacher development and to foster greater collaborative teacher learning (McLaughlin \& Talbert, 2006). Many versions of PLCs have been conceptualized and implemented within particular countries and around the world (e.g. Qiao, Yu, \& Zhang, 2017; Vescio, Ross, \& Adams, 2008). In critically reflecting on the wave of support internationally for PLCs, Hargreaves (1994) distinguished between genuine collegiality, in which teachers have agency within PLCs to collaborate about issues that matter to them in ways that support genuine and deep dialogue, and what he called "contrived collegiality", where teachers are told to collaborate about particular issues in ways that are often prescribed and that often undermine authentic communication.

A fourth general approach to supporting teacher agency and benefiting from teacher expertise is to de-privatize teaching and provide teachers opportunities to observe other teachers in action and to analyze what is observed, sometimes with the participation of the teachers observed. Here, as is the case with the strategies previously mentioned, there is great variety in how these observations are structured. For some teachers, observation of their peers is a regular part of their daily workday. In other cases, peer observation is a special activity that is available to teachers only occasionally. In one effort organized by the Center for Teaching Quality and Teaching Partners, two NGOs in the U.S., teachers conduct webinars and online workshops where they share aspects of their practice (including videos of their practice) with national audiences of other teachers and school administrators ${ }^{2}$. Various terms, such as "learning walks", "demonstration lessons", and "teaching rounds", have been used to describe peer observations, but the basic idea is that the teaching practices of individual teachers becomes more visible to the community of teachers and a collaborative culture within schools is fostered (Asia Society, 2017; City, Elmore, Fiarman, \& Teitel, 2009; DarlingHammond, Burns, et al. 2017; Ginsberg, 2011).

\section{BEYOND STRUCTURE: IT IS THE SUBSTANCE AND CULTURE THAT M A T T E R}

One important thing to know about these and other strategies for developing teacher agency and expertise is that each of them has been conceptualized and implemented in many different ways. It is not merely a question of the general structure of these forms of professional learning that determine their value in supporting teacher agency. It is also the culture that exists within these structures that gives them meaning and potential value. Whose knowledge counts in these forms of professional learning? Who gets to decide what teachers focus on and how they do so? Do teachers feel emotionally safe and supported so that they can be authentic? Do they feel intellectually challenged? There are many questions like these that need to be addressed before we can determine the usefulness of a particular instance of any of these strategies in supporting genuine teacher agency and in

${ }^{2}$ https://teachingpartners.com/workshops/archived/ 
creating opportunities to benefit from teacher expertise.

In the U.S., for example, all of the forms of teacher learning mentioned here have become very common, yet teachers still largely find their professional learning experiences to be not helpful. For example, in 2014, a Bill and Melinda Gates Foundation national evaluation found that:

The majority of school systems struggle to provide valuable professional learning experiences to teachers. The more than 1,600 teachers surveyed characterized their professional development as irrelevant, ineffective, and not connected to their core work of helping students learn. (cit. in Calvert, 2016, p. 2)

In another recent national evaluation, two prominent NGOs, the National Commission for Teaching and America's Future and Learning Forward, found that:

Even professional learning communities, a common form of professional learning, were consistently described (by teachers) as broken or seriously off track. One science teacher described PLCs as "a total cliché". An English teacher explained our conversation is superficial. We are afraid to bring up a situation that we are having, a problem, for fear of being judged. We are just going through the motions. (Calvert, 2016, p. 7)

A robust body of research exits identifies the features of professional learning experiences for teachers that are highly valued by teachers and that enhance education quality and equity for students (e.g., Calvert, 2016; DarlingHammond, Hyler, \& Gardner, 2017; Hargreaves \& O’Connor, 2018; Leana \& Frits, 2017; Qiao et al., 2017; Randi \& Zeichner, 2004; Vescio et al., 2008). This research has been translated into professional standards for teacher learning that address both the structure and culture of these learning experiences (e.g., Learning Forward, 2011). These features of high quality teacher professional learning opportunities call for professional learning that is ongoing, job-embedded, connected to practice, aligned to school and school district goals, and genuinely collaborative (Calvert, 2016). The literature also stresses the importance of teacher ownership of what they are working on, and a culture that provides an emotionally safe space where teachers feel they can be authentic and are supported and where they are also intellectually challenged (Zeichner, 2003).

\section{ENABLING TEACHERS VOICES TO BE HEARD IN EDUCATION P OLICYMAKING}

Generally, education officials around the world view the process of education reform as one involving the translation of policy initiatives into practice. In some parts of the world, these reforms are strongly directed by the visions and priorities of transnational organizations and development agencies such as the Organization for Economic Co-operation and Development (OECD) and the World Bank, in addition to, or rather than, by internal governments (Robertson, 2012). Regardless of the specific situation, it is very uncommon internationally for teachers to be given opportunities to help shape education policies and their implementation (Stromquist, 2018).

There are examples, though, in some of the high performing countries that we studied, in other countries, and in my own personal experience, of different strategies for engaging teachers in the conceptualization and development of education policies. For example, the Center for Teaching Quality (CTQ) in North Carolina, a NGO, has been very active in the U.S. in helping policymakers become more aware of classroom teachers perspectives on policy 
problems and their possible solutions. Utilizing their philanthropic support, they have organized teacher leadership groups across the country that interact with local and state policymakers. These teacher leaders share their perspectives through their blogs, teacher written policy briefs ${ }^{3}$, and through their public testimony to state education officials and legislators. A few years ago, I attended a meeting in Seattle where one of the local CTQ groups presented the findings contained in a policy brief on student and teacher assessment that they had written to state policymakers and representatives from local foundations such as the Bill and Melinda Gates Foundation.

Another example I became aware of in my research in Alberta, Canada, where I learned that teachers are frequently seconded from their classrooms for several years to work in the Ministry or teachers' association and then return to the classroom to be replaced by other teachers. The constant flow of teachers in and out of the Ministry of Education and the classroom ensures that teachers' perspectives are always present in the policy arena (Campbell et al., 2017).

Additionally, many states in the U.S. have Professional Educator Standards Boards that advise the state Board of Education and Chief School Officer about the governance of the teaching profession within individual states, including teacher education and the certification and professional learning for teachers. These teacher advisory groups advise the governmental bodies legally responsible for governing education on such things such as standards for teacher education programs and teacher certification, and regulations for teacher license renewal. In reality, there is much variation across states in the U.S. in the scope of responsibility and the degree to which the recommendations of these boards are acted on by government officials ${ }^{4}$.
6. THREE EXAMPLES OF THE IMPACT of Teacher Agency and Expertise ON EDUCATIONAL EQUITY PRACTICES AND POLICY

6.1 Example\#1 - The Alberta INitiative FOR SCHOOL IMPROVEMENT (AISI)

In 2000-2001, the Ministry of Education in the Canadian province of Alberta invested \$75,000 (about 2\% of its annual Education budget) in a comprehensive effort to support a three-year cycle of action research conducted by teachers, principals, students and community members focused on the creation of locally developed innovations to address both local needs and provincial priorities. This investment continued for three more 3-year cycles plus an additional two years, and in the end, after 14 years, over 1,800 action research projects had been funded in about 95\% of Alberta's schools (Campbell et al., 2017). In addition to the local benefits achieved by each local community from their own reform-based inquiries, the designers of the project built into AISI a deliberate strategy of "cross pollination" across schools. Several externally conducted evaluations of this work have documented the improvements in student learning and equity, as well as a number of other outcomes (e.g., Hargreaves \& Shirley, 2012).

One of the major areas in which both policy and practice were impacted by AISI is with regard to the education of Aboriginal students. For example, Gunn, Pomahac, Striker, and Tailfeathers (2011) examined 16 AISI projects focused on Aboriginal learning and identified a number of themes they addressed. These included improving the academic potential and learning of Aboriginal students, increasing the involvement of and communication with Aboriginal parents/guardians, creating a more

\footnotetext{
${ }^{3}$ https://www.teachingquality.org/wp-content/uploads/2018/04/How better teacher assessment can power up learning.pdf

${ }^{4}$ http://www.wsipp.wa.gov/ReportFile/725/Wsipp The-Washington-Professional-Educator-Standards-Board-Scope-of-Authorityand-Governance Full-Report.pdf
} 
inclusive sense of belong for Aboriginal students, and enhancing cultural awareness of Aboriginal culture and history throughout the education system. These inquiry projects show evidence of increasing attendance and the learning of Aboriginal students and resulted in policy changes that led to the creation of Aboriginal parent advisory councils and a provincial effort to prepare more Aboriginal teachers for Alberta's schools (Campbell et al., 2017).

\footnotetext{
6.2 Example \#2 - Teacher Classroom ACTION RESEARCH IN MADISON WISCONSIN (USA)
}

In 2000, a small pilot program was initiated by the district's professional learning department to support teachers and other practitioners in Madison schools to conduct year-long research about their own practices. After 30 years and several hundred studies that have been published by the district, the program continues today. Many of the teachers in the research groups were given one day per month released time for the group meetings and support from the district's librarians in accessing research studies related to their topics. The groups are led by facilitators who are teachers and other practitioners (e.g., counselors, social workers) who have experienced the action research process themselves. Teachers select their own research topics within broad group themes that are linked to priorities of the school district, such as race and social class equity and closing achievement gaps, multicultural education, inclusion, and teaching English learners. They have intellectual control of their own projects and the norms and structures within the research groups (see CaroBruce et al., 2007) ensure that the projects are teacher-directed.

An externally funded evaluation of the program for which I was one of the lead researchers (Zeichner, 2003) documented the many ways in which teachers' action research projects led to innovation in their classrooms and improved outcomes and equity for students. Importantly, this evaluation was also able to show how the research completed by the teachers (which was usually presented at a teacher research conference at the end of the school year and was also published by the district) influenced policies in the district with regard to the teaching of students with disabilities and the professional learning provided to teachers to do so (Bixby, Klehr, Zeichner, Caro-Bruce, \& Lyngaas, 2001).

\footnotetext{
6.3 Example \#3 - Inclusive Vs. Elite International BaCCalaureate Programs
}

The International Baccalaureate (IB) Program is a curriculum at the primary, middle and secondary levels that in 2016 existed in nearly 4,500 schools in 16 countries. This curriculum engages students in rigorous academic work. At the secondary level, students who participate in IB courses are engaged in college level work, based on a standard IB curriculum, and are taught by teachers who are trained and certified to teach IB courses. One problem that has been faced with this program is that it has often served as an elite program that has excluded many students living in poverty from participating in IB courses. This problem has been recognized by the IB organization that now provides grants to schools to help address the issue ${ }^{5}$.

In the Seattle Public Schools, the IB program exists in three high schools. In each of these high schools, teachers have worked very hard to make the IB courses widely accessible to many students in the school, instead of the common practice of the IB program serving as an exclusive program for academically successful students. In one of these schools, Ranier Beach High School, the adoption of the IB program

${ }^{5}$ https://www.ibo.org/excellence-and-equity/ 
was one of the key elements in changing this school that was about to be closed by the school district, making it one of the most successful schools in the district serving a diverse student population in a high poverty area of the city. In this school, in which about $40 \%$ of the students are refugees or immigrants, about $95 \%$ of the students are students of color, and where $75 \%$ of students live in poverty, teachers and parents worked together to bring the IB program into their school. Importantly, they insisted that the IB program serve all of the students in the school with particular attention given to the neighborhood's most underserved and marginalized students. This move to start an inclusive IB program in this school, and the agency of teachers and parents, in pushing for IB courses to be inclusive, resulted in the high school being selected for a national award (as a "School of Opportunity"), a process that documented many of the achievements of the school after the introduction of the IB program in improving the learning of students and equity within the school ${ }^{6}$ ?

\section{Conclusion}

This paper has summarized an argument for government officials who are responsible for education in their countries to support the development of genuine teacher agency with regard to their teaching and professional learning experiences, and to give teachers collectively a greater voice in the conceptualization and development of education policies. The goal here is to support teacher agency and to benefit from teachers' expertise in ways that are connected to system goals to provide everyone's children with access to well-prepared teachers and a high quality and enriching education that addresses academic, social-emotional, and civic aspects of learning and that reflects the multicultural and global realities that affect all nations. The reality today, in every country in the world, is that there are inequities both within their education systems and in the larger societies. I have argued, in this paper, that support for genuine teacher agency and consistent and honest leveraging teacher expertise can help ameliorate educational inequities.

Another one of the most important points that I have tried to make in presenting my arguments is that the structure of professional learning activities alone (e.g. teacher research, lesson study, professional learning communities) says very little about the quality of these experiences in relation to teacher agency and expertise. In order to understand how well these activities, in fact, support genuine learning and teacher agency and enable the system to benefit from individual and collective teacher expertise, we need to examine the culture and social relations that exist within them. The evidence suggests that both teacher and student learning are enhanced if a genuine culture of mutual trust, support, and intellectual challenge is present in teacher professional learning activities (Hargreaves \& O'Connor, 2018).

Do teachers have opportunities to focus their professional learning on issues that matter to them? Do they feel emotionally safe and respected as well as intellectually challenged in these activities? All of the different forms of professional learning that are described in this paper can be used in ways to empower teachers or to disempower and control them in more subtle ways that provide only an illusion of professional learning. There is still much important work to be done on all of the issues that are raised in this paper.

6 https://www.washingtonpost.com/news/answer-sheet/wp/2016/10/31/this-school-was-on-the-brink-of-closure-heres-how-it$\underline{\text { saved-itself/?utm term }=.09 \mathrm{c} 01 \mathrm{ce} 41370}$

${ }^{7}$ https://www.seattletimes.com/education-lab/seattles-rainier-beach-high-earns-national-spotlight-in-hbo-show-wyatt-cenacs-problem-areas/ 


\section{REFERENCES}

Asia Society. (March 2017). Empowering and enabling teachers to improve equity and outcomes for all. Summary of the proceedings of the International Summit on the Teaching Profession 2017. Edinburgh, U.K.

Atkin, M. (1994). Teacher research to change policy. In S. Hollingsworth \& H. Sockett (Eds.), Teacher research and educational reform (pp. 103-120). Chicago: University of Chicago Press.

Bixby, J., Klehr, M., Zeichner, K., Caro-Bruce, C., \& Lyngaas, K. (2001, April). From practice to policy: Using teacher action research to transform school district policies with regard to special education. Paper presented at the annual meeting of the American Educational Research Association, Seattle, WA.

Calvert, L. (2016). Moving from compliance to agency: What teachers need to make professional learning work. Oxford, $\mathrm{OH}$ : Learning Forward \& NCTAF.

Campbell, C., Zeichner, K., Lieberman, A., \& Osmond-Johnson, P. (Eds). (2017). Empowered educators in Canada. San Francisco: Jossey-Bass.

Caro-Bruce, C., Flessner, R., Klehr, M., \& Zeichner, K. (Eds). (2007). Creating equitable classrooms through action research. Thousand Oaks, CA: Sage.

City, E., Elmore, R. F., Fiarman, S. E., \& Teitel, L. (2009). Instructional rounds in education: A network approach to improving teaching. Cambridge, MA: Harvard Education Press.

Cochran-Smith, M., \& Lytle, S. (1993). Insideoutside: Teacher research and knowledge. New York: Teachers College Press.

Darling-Hammond, L., Burns, D., Campbell, C., Goodwin, A. L., Hammerness, K., Low, E.-L., ... Zeichner, K. (2017). Empowered educators: How high performing systems shape teaching quality around the world. San Francisco: Jossey-Bass.

Darling-Hammond, L., Hyler, M., \& Gardner, M. (2017). Effective teacher professional development. Palo Alto, CA: Learning Policy Institute. Retrieved from https://learningpolicyinstitute.org/ product/effective-teacher-professionaldevelopment-report

Day, C. (Ed.). (2012). International handbook of teacher and school development. London, U.K.: Routledge.

Ginsberg, M. B. (2011). Transformative professional learning. Thousand Oaks, CA: Sage.

Gunn, T. M., Pomahac, G., Striker, E., \& Tailfeathers, J. (2011). First Nations, Metis, and Inuit education: The Alberta Initiative for School Improvement approach to improve education in Alberta. Journal of Educational Change, 12(3), 323-345.

Hargreaves, A. (1994). Changing teachers, changing times: Teachers' work and culture in the postmodern age. New York: Teachers College Press.

Hargreaves, A., \& Fullan, M. (2012). Professional capital: Transforming teaching in every school. New York: Teachers College Press.

Hargreaves, A., \& O’Connor, M. T. (2018). Collaborative professionalism. Thousand Oaks, CA: Corwin.

Hargreaves, A., \& Shirley, D. (2012). The global fourth way: The quest for educational excellence. Thousand Oaks, CA: Corwin.

Hill, H. C., Beisiegel, M., \& Jacob, R. (2013). Professional development research: Consensus, crossroads, and challenges. Educational Researcher, 42(9), 476-487.

Jensen B., Sonnemann, J., Roberts-Hull, K., \& Hunter, A. (2016). Beyond PD: Teacher professional learning in high-performing systems. Washington, DC: National Center on Education and the Economy.

Leana, C. R., \& Frits, K. P. (2017). Social capital: An untapped resource for educational improvement. In E. Quintero (Ed.), Teaching in context: The social side of education reform (pp. 113-130). Cambridge, MA: Harvard Education Press. 
Learning Forward. (2011). Standards for professional learning. Oxford, OH: Author. Retrieved from https://learningforward.org/ standards-for-professional-learning

Lewis, C., \& Lee, C. (2018). The global spread of lesson study. In M. Akiba \& G. K. LeTendre (Eds.), International handbook of teacher quality and policy (pp.185-203). New York: Routledge.

McLaughlin, M. W., \& Talbert, J. C. (2006). Building school-based teacher learning communities. New York: Teachers College Press.

Priestley, M., Biesta, G., \& Robinson, S. (2015). Teacher agency: An ecological approach. London, U.K.: Bloomsbury.

Qiao, X., Yu, S., \& Zhang, L. (2017). A review of research on professional learning communities in mainland China 2006-2015. Educational Management, Administration and Leadership, 46(5), 713-728.

Randi, J., \& Zeichner, K. (2004). New visions of teacher professional development. In M. Smylie \& D. Miertszky (Eds.), Addressing teacher workforce issues effectively (pp. 180277). Chicago: University of Chicago Press.

Robertson, S. (2012). Placing teachers in global governance agendas. Comparative Education Review, 56(4), 584-607.

Stewart, V. (2012). A world-class education: Learning from international models of excellence and success. Alexandria, VA: Association for Supervision and Curriculum Development.

Stromquist, N. (2018). The global status of teachers and the teaching profession. Brussels, Belgium: Education International.

Tatto, T. (Ed.). (2007). Reforming teaching globally. Oxford, U.K.: Symposium Books.

Vescio, V., Ross, D., \& Adams, A. (2008). A review of the impact of professional learning communities on teaching and student learning. Teaching and Teacher Education, 24(1), 80-91.

Villegas-Reimers, E. (2003). Teacher professional development: An international review of the literature. Paris, France: UNESCO Institute for Educational Planning. Zeichner, K. (1993). Connecting genuine teacher development to the struggle for social justice. Journal of Education for Teaching, 19(1), 5-20.

Zeichner, K. (1995). Beyond the divide of teacher research and academic research. Teachers and Teaching: Research and Practice, 1(2), 153-172.

Zeichner, K. (2003). Teacher research as professional development for P-12 educators in the US. Educational Action Research, 11(2), 301-325.

Zeichner, K., \& Noffke, S. (2001). Practitioner research. In V. Richardson (Ed.), Handbook of research on teaching (4th ed., pp. 298-332). Washington, DC: American Educational Research Association. 


\section{A IMPORTÂnCIA DA Agência E DO CONHECIMENTO PROFISSIONAL DOS PROFESSORES NA REFORMA EDUCATIVA E NA DECISÃO POLÍTICA}

\section{RESUMO}

$\mathrm{O}$ artigo sustenta que a agência e o conhecimento profissional dos professores são frequentemente negligenciados nos sistemas educativos internacionais e que, instigando a sua maior capacidade de ação e melhor aproveitando e usando o seu conhecimento coletivo, os sistemas educativos podem tornarse mais bem-sucedidos e mais igualitários. Sumariam-se vários argumentos para que as entidades responsáveis pela educação nos seus países apoiem o incremento de uma genuína capacidade de ação dos professores, no que respeita às suas experiências de ensino e de desenvolvimento profissional, bem como lhes confiram uma voz mais ativa, coletivamente, na conceptualização e implementação de políticas educativas. O objetivo do artigo é apoiar esta capacidade de ação dos professores e demonstrar os benefícios de usufruir do seu saber e experiência, em articulação com os objetivos do sistema de proporcionar a todas as crianças um ensino por professores bem preparados e uma educação de elevada qualidade e enriquecedora, que lide com os aspetos académicos, socioemocionais e cívicos da aprendizagem e que reflita as realidades multiculturais e globais que afetam todas as nações.

Palavras-Chave: Agência profissional dos professores; Política docente; Conhecimento profissional docente

\author{
LA IMPORTANCIA DE LA AgENCIA \\ Y DEL CONOCIMIENTO PROFESIONAL \\ DOCENTE EN LA REFORMA EDUCATIVA \\ Y EN LA FORMULACIÓN DE POLÍTICAS
}

\section{RESUMEN}

El artículo sostiene que la agencia y el conocimiento profesional de los profesores son a menudo descuidados en los sistemas educativos internacionales y que, instigando una mayor capacidad de acción de los profesores y mejor aprovechando y usando su saber colectivo, los sistemas educativos tienen más éxito y son más igualitarios. Se sumarían varios argumentos para que los funcionarios gubernamentales que son responsables de la educación en sus países apoyen el incremento de una genuina capacidad de acción de los profesores, en lo que respecta a sus experiencias de enseñanza y de desarrollo profesional, y les otorguen una voz más activa, colectivamente, en la conceptualización y el desarrollo de políticas educativas. El objetivo del artículo es apoyar esta capacidad de acción de los profesores y demostrar las ventajas de beneficiarse de su saber y experiencia, en articulación con los objetivos del sistema de proporcionar a todos los niños una enseñanza por profesores bien preparados y una educación de alta calidad y enriquecedora, que lidia con los aspectos académicos, socio-emocionales y cívicos del aprendizaje y que refleja las realidades multiculturales y globales que afectan a todas las naciones.

Palabras-Clave: Agencia de los profesores; Política docente; Conocimiento profesional docente

\footnotetext{
${ }^{\text {I }}$ College of Education, University of Washington, United States of America.
}

Toda a correspondência relativa a este artigo deve ser enviada para: 